Paper Title: Contextual Factors: Assessing their influence on flow or resource efficiency orientations in healthcare lean projects

Keywords: lean thinking, lean projects, efficiency paradox, healthcare, contextual factors

First Author: Dr. Huay Ling Tay (Corrsponding Author)

Corresponding Author's details: Dr. Huay Ling Tay

School of Business, Singapore University of Social Sciences, Singapore

(65) 62480271

hltay@suss.edu.sg

Second Author: Professor Prakash J. Singh,

Department of Management \& Marketing, Faculty of Economics \& Commerce, The University of Melbourne, Melbourne, Australia,

(613) 83444713

pjsingh@unimelb.edu.au

Third Author: Associate Professor Vikram Bhakoo,

Department of Management \& Marketing, Faculty of Economics \& Commerce, The University of Melbourne, Melbourne, Australia,

(613) 83445320 ,

vbhakoo@unimelb.edu.au

Fourth Author: Dr. Shahid Al-Balushi

Sultan Qaboos University, Sultanate of Oman

shahid@squ.edu.om 


\title{
CONTEXTUAL FACTORS: ASSESSING THEIR INFLUENCE ON FLOW OR RESOURCE EFFICIENCY ORIENTATIONS IN HEALTHCARE LEAN PROJECTS
}

\begin{abstract}
The outcomes of lean projects have been mixed, with some being successful while many others have not. An explanation for this is a paradox that can develop depending on the focus of the project. Ironically, in projects where the focus is on maximizing the efficiency of a resource ('resource efficiency'), this focus might lead to worsening of the resource's efficiency, thereby generating an 'efficiency paradox'. This paradox does not usually arise in projects where the focus is on the subject of interest being processed through the system in the most efficient manner ('flow efficiency'). The aim of this paper is to investigate the factors that give rise to either form of efficiency. We conducted a detailed study of eight lean projects in two large hospitals. In doing so, we advance the theory of lean service operations by identifying four key contextual factors that drive the orientation of a project to resource or flow efficiency. These are: service variety, interdependency, capital resource intensity, and service uniqueness. We propose a conceptual framework and four propositions that integrate the contextual factors to determine the dominant focus in lean projects. Through this, recommendations are made as to how the efficiency paradox can be avoided.
\end{abstract}

Keywords: lean thinking, lean projects, efficiency paradox, healthcare, contextual factors 


\section{INTRODUCTION}

Many organizations have attempted to improve their operational processes using lean projects. While initially popular in the manufacturing sector, they have increasingly been applied in the service sector, as well (e.g., LaGanga 2011; Staats et al. 2011; Staats and Upton 2011). The outcomes, however, have been variable, with some projects being successful while others were not (e.g., Seddon 2011; Taylor et al. 2013; Waring and Bishop 2010).

According to the literature, a potential explanation for this equivocal state is a paradox that can develop depending on the focus of the lean project (Modig and Åhlström 2012). If the focus is on maximizing the efficiency of a 'resource', without consideration to how this resource integrates with other elements of the system, then, paradoxically, the worse the efficiency of the system will become. For instance, if the focus at a hospital is to optimize the use of operating theaters in the surgical department by maximizing the booking of surgical operation slots, without considering how the surgical department is connected to the wider hospital system, the overall service time for the patient will be longer.

To avoid this paradoxical situation, Modig and Ahlstrom (2012) argue that an organization should focus its efforts on optimizing the 'flow' of the subjects in the system rather than seek to locally optimize the efficiency of individual resources within the system. While this view of how lean projects can be more effective is intuitively appealing, little empirical research exists that examines how organizations fall into the trap of the efficiency paradox, and how they can systematically focus on flow efficiency.

In this study, we seek to develop a deeper understanding of the factors that lead to a lean project developing a resource or flow efficiency orientation. We focus on identifying the key contextual factors that drive the two forms of efficiency in lean projects. Specifically, we address the research question: What are the contextual factors that drive the orientation of 
lean projects to either resource or flow efficiency?

We address this research question in the context of the healthcare services sector. We chose the healthcare sector because it has been under increasing pressure to improve their service delivery processes using lean practices. However, the outcomes of these initiatives have been mixed. This has been attributed to the complexity of healthcare services, which stems from the interactions among clinical and front line staff and among staff and patients, the type of services offered, different (and often conflicting) performance objectives, and the necessity for inter-departmental integration in hospitals (Shah et al. 2008).

To develop a deeper understanding of the factors that drive the orientation of lean projects to either resource or flow efficiency, we conducted eight detailed case studies of lean projects involving diverse functional groups from two large hospitals in Singapore. Multiple types of data were collected and analyzed to inductively determine the salient contextual factors that have an influence on the way lean is being adapted in specific contexts and the dominant focus on lean projects. Our findings reveal four contextual factors: service variety, interdependency, capital resource intensity, and service uniqueness.

Our study makes several important contributions. First, we contribute to lean literature by providing a deeper understanding of the efficiency paradox in healthcare service operations and, thereby, respond to scholarly calls to provide a better appreciation of the operations challenges in improvement initiatives that are primarily driven by the lean philosophy (e.g., Bamford et al. 2015; Marley and Ward 2013; Taylor et al. 2013). We do so by proposing a conceptual framework and four propositions that connect contextual factors to the dominant efficiency focus in lean projects, thus extending theory in lean service operations. The framework and propositions provide a deeper insight into how the two forms of efficiency can develop in lean projects under variant contextual conditions. These findings are significant, as they aid managers in adapting lean in variant contexts to successfully achieve 
the desired outcomes in more certain and predictable ways (McDermott and Venditti 2015; Radnor et al. 2012; Waring and Bishop 2010).

Second, extant research in lean mostly focuses on the implication of contextual factors on lean initiatives in industrial operation settings. For instance, contextual factors such as plant characteristics, unionization status of industrial firms, human factors, and job characteristics that are involved in the work processes have been studied by De Treville and Antonakis (2006) and Shah and Ward (2003). While these contextual factors play a significant role in the traditional industrial or manufacturing contexts, scholars are unsure of their relevance in the service operations context.

Third, our study adds to the understanding of the efficiency paradox by providing empirical evidence on the manifestations of the paradox based on our in-depth case research. We do so by building on the work of Modig and Åhlström (2012) who have expounded on the characteristics of flow efficiency and resource efficiency, and their connections with the efficiency paradox. Our study advances this understanding by highlighting the role of four contextual factors that drive the orientation of lean projects, thereby providing a deeper understanding of the efficiency paradox.

\section{LITERATURE REVIEW}

\subsection{Lean Approach}

Lean thinking started with Toyota Motor Corporation in the 1950s. The term was coined by Krafcik (1988). It offers guidance in how to provide what the customer wants, quickly, efficiently, and with little waste. It is considered a radical alternative to the traditional method of mass production and batching principles for optimal efficiency, quality, speed, and cost (Holweg 2007; New 2007; Pegels 1984).

Womack et al. (1990) define lean as a dual customer and process-focused approach in their five principles of lean. Process improvement is dominant in these principles. A large 
number of tools and techniques have been proposed for this purpose (Shah and Ward 2003; Shah and Ward 2007). The lean approach is based on the motivation to improve efficiency through the integration of processes and connected elements across interfaces so as to achieve a continuous flow of products/service units and pull processes between all the steps (Womack and Jones 1996).

\subsection{Lean in healthcare services}

Service operations face the continuing challenge of matching consumer demand with provider supply, and healthcare services have been the focus of much concern and attention (LaGanga 2011). Timely access, responsiveness to patient needs, and availability are key priorities among healthcare system improvements earmarked by the Institute of Medicine (2001).

Recently, the healthcare sector has made significant progress in adapting lean principles in its operations. Applications to healthcare contexts have seen the forms of minimization or elimination of delays, repeated encounters, errors, and inappropriate procedures (e.g., Anand et al. 2012; McDermott and Venditti 2015; Meredith et al. 2011). The sector has a record of adopting lean principles, especially in the mainly independent (or private) US healthcare system. A prime example of this is the Virginia Mason Medical Center, an acute care hospital in Seattle (Weber 2006). It uses tools such as Rapid Process Improvement Workshops, 5S, value-stream mapping, 'Everyday lean', and Kanban to extensively improve both quality and flow, including reducing staff walking distances, inventory, and lead time by half. Royal Bolton NHS Foundation Trust is the closest to a complete application of lean in the UK (Radnor 2010).

However, critics on the use of lean practices in healthcare settings have recently questioned the fit and promise of lean practices, citing literature that suggests some healthcare organizations are implementing lean in a piecemeal manner using simple tools and 
techniques in small enclosed projects, which are merely creating 'pockets of best practice' (De Souza 2009; Radnor 2011; Spear 2005). They highlight that most of these lean practices are implemented in a disjointed manner, and are narrow in scope and tool-based within a single department. For instance, Spear (2005) argues that: "in healthcare, no organization has fully institutionalized to Toyota's level the ability to design and improve work through experiments, share the resulting knowledge through collaborative experimentation and develop people as experimentalists". Radnor et al. (2012) conclude that there are many instances of lean strategies that impact organizational performance to a less than anticipated extent, due to poor implementations of lean that are often accompanied by an incomplete understanding of the fundamental principles and the influence of contextual factors. This work shows that lean is context-dependent and there is no shortcut to understanding its underlying assumptions and fundamental principles (Radnor et al. 2012). Such ambiguities in the outcomes of lean healthcare call for more attention to the way in which lean is translated and implemented.

\subsection{Lean Outcomes - Resource Efficiency, Flow Efficiency, and Efficiency Paradox}

While research has attested to the mixed outcomes of lean projects, so far, most of the studies that have attempted to provide explanations for this have focused on how lean is applied. These studies examine whether lean has been employed merely as a tool kit or applied at the system-wide level (Arlbjørn and Freytag 2013; Holweg 2007; Radnor et al. 2012). We propose a complementary perspective to this, based on the 'efficiency paradox' concept, to extend understanding on the mixed outcomes.

According to Modig and Åhlström (2012), the efficiency paradox arises when efficiency of individual resources is pursued. This paradox stems from a dominant focus on maximizing the efficiency of individual resources without due regard to how the individual pockets of resource efficiency can be integrated into the entire operation system. This way of looking at 
efficiency is termed 'resource efficiency'.

With a resource efficiency perspective, there is little consideration of the interconnectedness of all the resources that make up the overall system. The internal intraorganizational/departmental boundaries demarcate elements and resources when following resource efficiency (Hillman et al. 2011; Meijboom et al. 2010). This encourages a silo view and a localized approach to achieve internal process optimization at the departmental level (Coelli et al. 2005; Lee et al. 2009; Van Aken 2010). This results in a subsequent paradoxical outcome. According to Meyer Jr. et al. (2012), instead of becoming more efficient, the system becomes more inefficient and generates more waste, while maximizing the efficiency of individual resources. We illustrate the manifestation of resource efficiency in a healthcare context similar to Modig and Ahlstrom's (2012). For instance, in a primary care hospital, each department will tend to specialize in a specific task or function that serves to meet parts of the patient care journey within the hospital. In doing so, the focus is on maximizing the use of individual resources or functions at the departmental or sub-unit level. A patient requiring a diagnosis may have to wait for long periods of time (and in some cases, even days) to have an MRI Scan, X-Ray and/or other tests in order to get a correct diagnosis. This is essentially because each department is seeking to optimize the use of resources within their department. This results in long throughput time, many flow units, and numerous restarts resulting from many changeovers or handovers in the hospital context.

Flow efficiency, on the other hand, emphasizes 'the unit' processes in an organization and is defined from the perspective of the 'flow unit'. Within the services context, the flow unit is often a customer whose needs are met through a range of different activities. In the healthcare context, this flow unit can be the individual patient who arrives at the hospital. This can also be an order for diagnostic tests, a discharge form, or a bill. In this study, we focus on the individual patient as the main unit that flows through a hospital's healthcare delivery process. 
Therefore, flow efficiency is a measurement of how much a patient is 'processed' from the time a patient's need is identified to the time the need is satisfied (Ahlstrom 2004; Meyer Jr et al. 2012). The value is defined from the patient's perspective. In the hospital, flow efficiency is measured by the percentage of time used for value-adding activities with respect to the total throughput time. When applying flow efficiency in a healthcare context, it is important to understand both direct and indirect needs. Direct needs deal with diagnosis and treatment, whereas indirect needs relate to the experience. Flow efficiency is about determining the right balance between direct and indirect needs to best serve the patient. Resources are reconfigured to serve the needs of the patient in a timely manner. To ensure timely treatment, there are times when resources are not being used. In flow efficiency, throughput time is short, there are few flow units (or patients), and few restarts in the healthcare service processes (Modig and Åhlström 2012).

Summarizing, the two types of efficiency differ in their focus, goal, and perception of the organization, as well as in the desired forms of competence, types of needs fulfilled, throughput time, number of units, and restarts in the processes. Table 1 provides a delineation of the resource efficiency and flow efficiency based on the fore-mentioned attributes.

Table 1: Delineation of the resource efficiency and flow efficiency

\begin{tabular}{|l|l|l|}
\hline \multicolumn{1}{|c|}{ Attributes } & Resource Efficiency & Flow Efficiency \\
\hline Focus & Resources/ Functions & Unit \\
\hline Goal & High capacity utilization & Fulfill needs \\
\hline Organizational View & Parts/ "Islands" & System/ "Ocean" \\
\hline Competence & Specialist/ "Depth" & Multi-Competence/ "Width" \\
\hline Types of Needs Fulfilled & Direct & Indirect \\
\hline Throughput time & Long & Short \\
\hline Number of Units & Many & Few \\
\hline Number of Restarts & Many & Few \\
\hline
\end{tabular}




\subsection{Contextual Factors Affecting the Efficiency Paradox}

Despite the growth of lean initiatives, little consensus exists in terms of the contextual factors that contribute to projects attaining successful outcomes, specifically within a healthcare context. This literature gets patchier when discussed in the light of the efficiency paradox. Shah and Ward (2003) demonstrate that organization size has a strong influence on lean implementation, whereas level of unionization and age of the organization are less influential. Dahlgaard and Dahlgaard-Park (2006) suggest that, for the success of lean projects, employee training and tools/techniques are less effective compared to the human factors associated with company culture. Along a similar line, Balle (2005) claims that successful lean implementation requires a systems "attitude" rather than a toolbox perspective, and that this attitude has strong cognitive, affective, and behavioral dimensions. Arkader (2001) focuses on the development status of the country context, and concludes that organizations in developing countries face both organizational and business environmental barriers to successfully using lean principles. De Treville and Antonakis (2006) applied the Job Characteristics Model to the lean production context to explain the theoretical relationship between job characteristics and motivational outcomes in lean production. The authors conclude that lean production job design may engender worker intrinsic motivation; however, there are likely to be substantial differences in intrinsic motivation under differing lean production configurations.

The above studies highlight two critical issues. First, most of these studies have been conducted in the manufacturing sector, leading to valid concerns about the generalizability of these results to service contexts such as healthcare. Second, it is not clear how contextual factors influence the success of lean projects. This is particularly so for healthcare organizations such as hospitals, where the required levels of competency and skills to meet patients' needs are highly diverse. Overall, there is a lack of consensus on the influence of 
contextual factors that are peculiar to the manifestation of the efficiency paradox in lean projects.

In view of these issues, this study responds to scholarly calls for further research to bridge this understudied area (e.g., Anand et al. 2012; DelliFraine et al. 2010; McDermott and Venditti 2015). We aim to bridge this gap through this study by providing a deeper understanding of the factors that lead to a lean project developing a resource or flow efficiency orientation. We do so by addressing the research question: What are the contextual factors that drive the orientation of lean projects to either resource or flow efficiency? Through this study, we extend theory by providing a deepened understanding of the efficiency paradox. We aim to understand how different projects, embedded within the healthcare context, may lead to manifestation of the efficiency paradox in lean projects.

\section{RESEARCH METHOD}

\subsection{Overview of Empirical Context}

As discussed above, there is extensive literature on lean ideology within the manufacturing context. However, the scholarly discourse on the efficiency paradox gets patchy within the healthcare services domain. Therefore, we adopted a case study methodology for theory extension to further our understanding of the efficiency paradox and how it is affected by contextual factors (Gioia et al. 2013; Strauss and Corbin 1990).

We conducted our case studies in two large public Singaporean hospitals. The two hospitals were similar in terms of their organizational structures, capacities, range of multidisciplinary healthcare services offered, and operational activities carried out. Two hospitals were chosen instead of one to ensure that the findings were not too idiosyncratic to one organization. Our rationale for selecting two similar hospitals was to obtain access to a broad range of lean projects that had been initiated by these hospitals. We also wanted to maintain a balance between heterogeneity and homogeneity in our lean cases. Hospitals typically design 
projects to improve their internal operations using lean methodologies (e.g., Papadopoulos et al. 2011). In the two hospitals studied, these projects were referred to as Rapid Improvement

Events (RIEs). Table 2 provides an overview of the empirical sites that were studied.

Table 2: Overview of empirical sites

\begin{tabular}{|l|l|}
\hline Organization & Hospital profile, specialties, and organizational structures \\
\hline Hospital A & $\begin{array}{l}\text { Established in January 2008. It is a teaching hospital with a tripartite mission of } \\
\text { excellence in clinical care, translational clinical research, and education. These } \\
\text { include training healthcare providers and scientists while conducting research } \\
\text { that focuses on bringing solutions to major healthcare challenges in Singapore. } \\
\text { Comprehensive infrastructure is being developed to include extensive research } \\
\text { and education facilities. }\end{array}$ \\
\hline $\begin{array}{l}\text { The wide range of medical specialties includes cardiology, gastroenterology and } \\
\text { hepatology, obstetrics and gynaecology, oncology, ophthalmology, paediatrics, } \\
\text { orthopaedic surgery, and hand and reconstructive microsurgery. }\end{array}$ \\
\hline Hospital B & $\begin{array}{l}\text { One of Singapore's largest multi-disciplinary hospitals. 40 clinical and allied } \\
\text { health departments, 16 specialty centers and powered by more than 7,000 } \\
\text { healthcare staff. This hospital sees over 2,000 patients in its specialist clinics and } \\
\text { some 460 patients in its emergency department every day. }\end{array}$ \\
$\begin{array}{l}\text { Hospital B is steeped in patient safety and quality culture. It constantly } \\
\text { challenges itself to provide faster, better, cheaper, and safer care for patients. To } \\
\text { achieve this, the hospital keeps abreast of patients' changing needs and believes } \\
\text { in investing in its staff, facilities, medical technology, and system } \\
\text { improvements. }\end{array}$ \\
\hline
\end{tabular}

\subsection{Research Design}

For this study, we used purposeful sampling to select eight RIE projects involving multiple disciplinary groups, job functions, and departments across the hospitals. This was done to enable theoretical replication and to maximize learning opportunities (Eisenhardt 1989; Stake 1995). The eight RIEs were selected to represent clinical functions (e.g., surgical department), as well as non-clinical functions (e.g., housekeeping and porter services). In 
addition, two polar cases were examined to maximize learning from the multiple case studies (Yin 2003): a streamlined death registration process, and a specialized care process for elderly patients. Each project formed a case as the primary unit of analysis. Of the eight projects, three were smaller scale projects that were initiated at the department level (RIEs 1, 2, and 3). The other five (RIEs 4, 5, 6, 7 and 8) were parts of larger program initiatives organized at the hospital level that aimed to align with the key corporate performance indicators reported on a rolling basis at the national level. Table 3 provides an overview of the data sources and information on the eight RIE projects. 
Table 3: Overview of data sources and lean projects (RIEs)

\begin{tabular}{|c|c|c|c|c|c|c|}
\hline $\begin{array}{l}\text { Lean project } \\
\text { (RIE) }\end{array}$ & Project description and scope & $\begin{array}{l}\text { Project team } \\
\text { composition }\end{array}$ & Desired outcomes & \begin{tabular}{|l|}
$\begin{array}{l}\text { Performance } \\
\text { measures }\end{array}$ \\
\end{tabular} & $\begin{array}{l}\text { Hospital } \\
\text { A/B } \\
\end{array}$ & Data sources \\
\hline $\begin{array}{l}\text { (1) Inpatient } \\
\text { ward discharge } \\
\text { process }\end{array}$ & $\begin{array}{l}\text { To increase more patients' discharge } \\
\text { before noon by increasing the usage } \\
\text { of discharge lounge facilities in ward }\end{array}$ & $\begin{array}{l}\text { Include only internal } \\
\text { ward personnel }\end{array}$ & $\begin{array}{l}\text { Increase rate of patient } \\
\text { discharges by improving } \\
\text { utilization of discharge lounge }\end{array}$ & $\begin{array}{l}\text { Intradepartmental } \\
\text { outcome measures }\end{array}$ & A & $\begin{array}{l}3 \text { interviews } \\
3 \text { project meetings } \\
1 \text { RIE participation }\end{array}$ \\
\hline $\begin{array}{l}\text { (2) Surgical } \\
\text { Department } \\
\text { operations }\end{array}$ & $\begin{array}{l}\text { To reduce the number of no shows } \\
\text { and cancellations with internal work } \\
\text { flow redesign - Target less than } 10 \% \\
\text { no-shows or cancellations }\end{array}$ & $\begin{array}{l}\text { Include only surgical } \\
\text { department personnel }\end{array}$ & $\begin{array}{l}\text { Improve resource utilization rate } \\
\text { of surgical facilities and } \\
\text { equipment }\end{array}$ & $\begin{array}{l}\text { Intradepartmental } \\
\text { outcome measures }\end{array}$ & $\mathrm{A}$ & $\begin{array}{l}2 \text { interviews } \\
1 \text { RIE participation } \\
1 \text { project site } \\
\text { observation }\end{array}$ \\
\hline $\begin{array}{l}\text { (3) ECHO } \\
\text { (Cardiac } \\
\text { Echocardiograp } \\
\text { hy Machine) }\end{array}$ & $\begin{array}{l}\text { To maximize the use of existing } \\
\text { Cardiac Echocardiography Machine } \\
\text { and peripheral resources }\end{array}$ & $\begin{array}{l}\text { Include only internal } \\
\text { personnel from Heart } \\
\text { Center }\end{array}$ & $\begin{array}{l}\text { Improve scheduling of scans to } \\
\text { optimize the use of ECHO } \\
\text { machines }\end{array}$ & $\begin{array}{l}\text { Intradepartmental } \\
\text { outcome measures }\end{array}$ & A & $\begin{array}{l}3 \text { interviews } \\
3 \text { project meetings } \\
2 \text { project site } \\
\text { observations } \\
1 \text { RIE participation }\end{array}$ \\
\hline $\begin{array}{l}\text { (4) Oncology } \\
\text { department/ } \\
\text { Cancer center }\end{array}$ & $\begin{array}{l}\text { To coordinate appointment booking } \\
\text { and treatment processes of both } \\
\text { radiography and chemotherapy }\end{array}$ & $\begin{array}{l}\text { Include internal staff } \\
\text { and interfacing } \\
\text { department involved in } \\
\text { the coordination } \\
\text { process }\end{array}$ & $\begin{array}{l}\text { Improve coordination and } \\
\text { provide a clear conduit of work } \\
\text { flow across interfaces for } \\
\text { multiple-tumor cancer patients to } \\
\text { undergo same-day chemotherapy } \\
\text { and radiotherapy treatments }\end{array}$ & $\begin{array}{l}\text { Cross-department } \\
\text { outcome measures }\end{array}$ & A \& B & $\begin{array}{l}2 \text { interviews } \\
2 \text { project meetings } \\
1 \text { project site } \\
\text { observation } \\
1 \text { RIE participation }\end{array}$ \\
\hline $\begin{array}{l}\text { (5) } \\
\text { Housekeeping } \\
\text { operations }\end{array}$ & $\begin{array}{l}\text { To satisfy greater demand through } \\
\text { the management of existing } \\
\text { processes }\end{array}$ & $\begin{array}{l}\text { Include personnel from } \\
\text { the interfacing } \\
\text { departments }\end{array}$ & $\begin{array}{l}\text { Improve information exchange } \\
\text { and coordination to reduce wait } \\
\text { times in inpatient transfers and } \\
\text { admission }\end{array}$ & $\begin{array}{l}\text { Cross-department } \\
\text { outcome measures }\end{array}$ & $\mathrm{B}$ & $\begin{array}{l}2 \text { interviews } \\
2 \text { project meetings } \\
1 \text { project site } \\
\text { observation }\end{array}$ \\
\hline $\begin{array}{l}\text { (6) Closed Loop } \\
\text { dispensary } \\
\text { system }\end{array}$ & $\begin{array}{l}\text { To achieve better coordination and } \\
\text { accuracy of drug replenishments in } \\
\text { the wards }\end{array}$ & $\begin{array}{l}\text { Include personnel from } \\
\text { the interfacing } \\
\text { departments }\end{array}$ & $\begin{array}{l}\text { Enhance coordination for } \\
\text { accurate and timely } \\
\text { replenishment of drugs }\end{array}$ & $\begin{array}{l}\text { Cross-department } \\
\text { outcome measures }\end{array}$ & $\mathrm{B}$ & $\begin{array}{l}3 \text { interviews } \\
1 \text { project site } \\
\text { observation } \\
2 \text { survey responses }\end{array}$ \\
\hline $\begin{array}{l}\text { (7) Focused } \\
\text { care program } \\
\text { for elderly } \\
\text { patients }\end{array}$ & $\begin{array}{l}\text { To direct better care toward elderly } \\
\text { patients who require acute care } \\
\text { support }\end{array}$ & $\begin{array}{l}\text { Include personnel from } \\
\text { the interfacing } \\
\text { departments }\end{array}$ & $\begin{array}{l}\text { Improve coordination and } \\
\text { patient flow to the right site of } \\
\text { care }\end{array}$ & $\begin{array}{l}\text { Cross-department } \\
\text { outcome measures }\end{array}$ & $\mathrm{B}$ & $\begin{array}{l}4 \text { interviews } \\
2 \text { project meetings } \\
1 \text { project site } \\
\text { observation }\end{array}$ \\
\hline $\begin{array}{l}\text { (8) Death } \\
\text { Registration } \\
\text { process }\end{array}$ & $\begin{array}{l}\text { To speed up the process and lead } \\
\text { time of death registration within the } \\
\text { hospital }\end{array}$ & $\begin{array}{l}\text { Include personnel from } \\
\text { the interfacing } \\
\text { departments }\end{array}$ & $\begin{array}{l}\text { Improve coordination among } \\
\text { several departments to ensure } \\
\text { same-day death registration }\end{array}$ & $\begin{array}{l}\text { Cross-department } \\
\text { outcome measures }\end{array}$ & $\mathrm{A}$ & $\begin{array}{l}3 \text { interviews } \\
1 \text { project meeting } \\
1 \text { RIE participation }\end{array}$ \\
\hline
\end{tabular}




\subsection{Data Collection}

Data collection occurred over a seven-month period, from August 2012 until February 2013. The primary source of data was semi-structured interviews conducted with a range of people associated with each RIE. Those interviewed included at least one senior manager, the improvement project leader, team members, staff members who were affected by the change, relevant middle managers, and service professionals. In addition, we ensured the reliability of our findings by drawing data from other sources, including site visits, observations of project meetings and events, analysis of project implementation reports, organizations' annual reports and internal management documents, such as meeting minutes and reports.

The main sources of data for our research were semi-structured interviews. The interviews were all conducted face to face and generally lasted between one and two hours. To enhance the validity and reliability of the findings from the multiple case studies, the semi-structured interview protocol (Appendix A) was developed based on previous studies that had focused on lean (e.g., Holweg 2007; Hopp and Spearman 2004; Womack and Jones 1996). All the interviews were recorded and subsequently transcribed. The primary researcher also spent a lot of time in the hospitals observing the processes and interactions between clinical/nonclinical staff and patients. Comprehensive notes were taken during this process. Any unclear issues were clarified in follow-up telephone interviews or emails. Table 3 provides an overview of the cases and interviews.

Following each case study, the data was analyzed and a report was written highlighting the findings under each of the key topics identified in the semi-structured interview protocol. To increase interpretative validity, this report was then sent to a senior manager so that the data was validated for the case study. In all, the data included more than 500 pages of field notes and over 82 hours of audiotapes of meetings and interviews. 


\subsection{Data Coding and Analysis}

The data coding and analysis involved two phases. In the first phase, we focused on identifying the dominant type of efficiency pursued within the respective RIE cases. We did this by identifying the key attributes provided in Table 1 that were relevant to each RIE. In the second phase, we focused on understanding and subsequently developing a list of contextual factors that influence the orientation of lean initiatives.

\subsubsection{First Phase Data Coding and Analysis}

We began by writing up case histories for each lean project (Eisenhardt 1989), and we attempted to generate internally consistent descriptions of each project case. In parallel, we worked on the descriptions of each lean project, based on project charters that define the aims and background of the improvement initiatives and additional material relevant to each project. The next stage started with the open coding (Strauss and Corbin 1990) of the interviews by grouping phrases, sentences, or paragraphs into codes and categories in an inductive fashion. Once we finished coding the interviews, we began with axial coding to generate more abstract codes and to delete and merge codes (Strauss and Corbin 1990). During this stage, we started to connect our inductive codes to the established constructs, resource efficiency and flow efficiency.

We focused on the attributes listed in Table 1 to distinguish the cases with respect to the two forms of efficiency: resource efficiency or flow efficiency. For instance, it is common to see long queues and long waiting times at the various specialty or patient service functions in hospitals. Somewhat counterintuitively, to be resource efficient results in queues, and these queues must wait to get work done. Therefore, in our analysis, when resource efficiency is the main goal, performance of the specific department/function is fundamentally measured based on the time the resource is utilized in the overall time period, resulting in long queues and waiting times in the system. On the other hand, when the same task is operating based on 
flow efficiency, defined as the value-added time spent on the flow item (or customer demand or requirement/service to be administered), the focus is on meeting the needs of the patient instead of keeping the resource busy.

The first and second authors went through the transcripts and coded them independently, using specific guidelines established through discussions and review of the literature. Any ambiguities were resolved through detailed discussions. Overall, there was high inter-rater reliability $(95 \%)$.

\subsubsection{Second Phase Data Analysis - Identification of Contextual Factors}

In the second phase of our data analysis, the inductive coding and the within- and crosscase analysis that was conducted facilitated in developing specific contextual factors that resulted in projects developing an orientation toward either a resource or flow efficiency perspective. We used the inductive thematic coding approach (Van Maanen 1979) involving a thorough coding of the interview and meeting transcripts. We relied on the informants' own language (Strauss and Corbin 1990) as the source for labeling the key descriptive themes. This resulted in developing the data structure illustrated in Figure 1. Our inductive thematic coding approach resulted in a coding scheme consisting of 17 primary inductive codes.

The constant comparative method resulted in 12 key descriptive themes emerging from the 17 primary inductive codes (see Figure 1 for details). The key contextual factors were generated from a third order analytical synthesis through the application of a higher-level theoretical framework (our research question and prior literature on lean, service operations and the efficiency paradox). As this figure shows, the four factors that resulted from this analysis were service variety, interdependency, capital resource intensity, and uniqueness of services. 


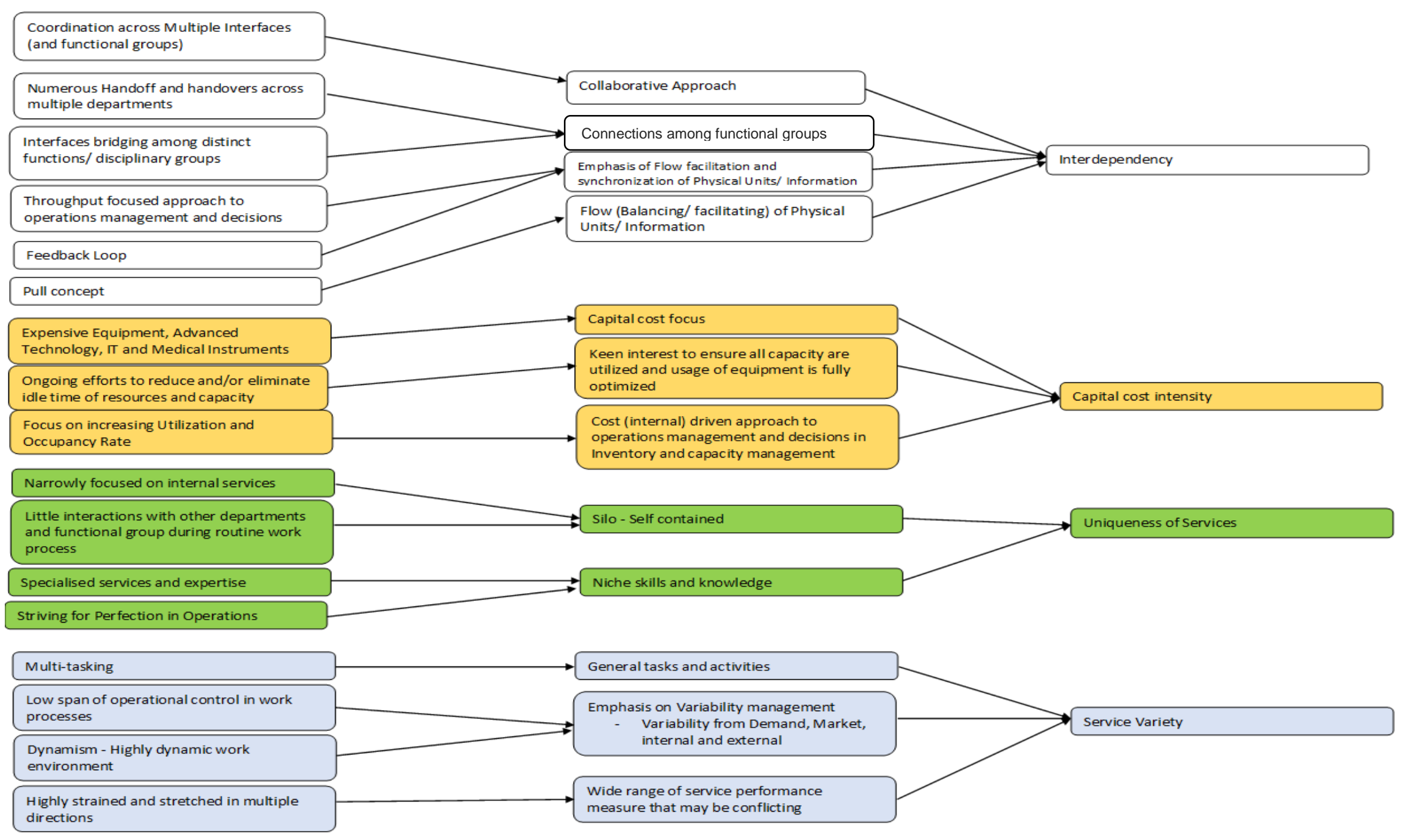

Figure 1: Data Structure 
Table 4 provides descriptions and representative supporting quotes for resource efficiency,

flow efficiency, and each of the four contextual factors generated from the inductive thematic

synthesis. Appendix B provides more representative quotes of the four context factors.

Table 4: Description and representative quotes of resource efficiency, flow efficiency and the contextual factors

\begin{tabular}{|c|c|c|c|}
\hline Contextual factor & Description & Representative quotes & Case \\
\hline Resource efficiency & $\begin{array}{l}\text { Dominant focus is on } \\
\text { maximizing the efficiency } \\
\text { of individual resource/ } \\
\text { function with little regard } \\
\text { for how the individual } \\
\text { function /resource is } \\
\text { connected to the entire } \\
\text { operations system. }\end{array}$ & $\begin{array}{l}\text { "We cannot afford to have any } \\
\text { resource lying idle. Equipment } \\
\text { are brought in at a very high } \\
\text { cost, we need to ensure they are } \\
\text { fully utilized at all times. Idle } \\
\text { time is definitely a waste; we } \\
\text { have to improve the current rate } \\
\text { of utilization." }\end{array}$ & $\begin{array}{l}\text { RIE 3: Echo- } \\
\text { cardiography } \\
\text { (ECHO) } \\
\text { department }\end{array}$ \\
\hline Flow efficiency & $\begin{array}{l}\text { A holistic systemic view } \\
\text { that focuses on entire } \\
\text { system, it measures how } \\
\text { much a patient is } \\
\text { 'processed' from the time } \\
\text { a need of the patient is } \\
\text { identified to the time the } \\
\text { need is satisfied } \\
\text { (Ahlstrom 2004; Meyer Jr } \\
\text { et al. 2012). For instance, } \\
\text { in the hospital, the } \\
\text { percentage of time used } \\
\text { for value adding activities } \\
\text { for patients is measured } \\
\text { with respect to the total } \\
\text { throughput time. }\end{array}$ & $\begin{array}{l}\text { "The fact is we are very much } \\
\text { integrated. I mean, we are part } \\
\text { of the patient's flow, patient's } \\
\text { journey. Nature of healthcare } \\
\text { operations is dynamic. Patient's } \\
\text { needs translate to operational } \\
\text { demands that are constantly in } \\
\text { flux. So, our key challenge is to } \\
\text { be able to keep up with the } \\
\text { dynamism to meet the diverse } \\
\text { needs of patients by performing } \\
\text { numerous tasks and services to } \\
\text { best serve our patients' needs." }\end{array}$ & $\begin{array}{l}\text { RIE 8: Death } \\
\text { Registration } \\
\text { RIE }\end{array}$ \\
\hline Service variety & $\begin{array}{l}\text { The range of distinct } \\
\text { services provided/offered } \\
\text { under the scope of the } \\
\text { improvement project. }\end{array}$ & $\begin{array}{l}\text { "To satisfy the increasing } \\
\text { demand of housekeeping, there } \\
\text { are different KPI and } \\
\text { performance measures for the } \\
\text { various service requests. On a } \\
\text { daily basis, we need to carry out } \\
\text { a wide range of work activities } \\
\text { and tasks in order to deliver the } \\
\text { required services and care } \\
\text { demanded by the broad } \\
\text { spectrum of patient profiles." }\end{array}$ & $\begin{array}{l}\text { RIE 5: } \\
\text { Housekeeping } \\
\text { operations }\end{array}$ \\
\hline Capital cost intensity & $\begin{array}{l}\text { The ratio of incurred } \\
\text { capital costs to } \\
\text { labor/manpower cost. }\end{array}$ & $\begin{array}{l}\text { "Our objective was to eliminate } \\
\text { all forms of waste and expedite } \\
\text { the necessary work to be carried } \\
\text { out as to keep our expensive } \\
\text { medical equipment utilized and } \\
\text { operating space occupied at a }\end{array}$ & $\begin{array}{l}\text { RIE 2: } \\
\text { Surgical } \\
\text { department }\end{array}$ \\
\hline
\end{tabular}




\begin{tabular}{|c|c|c|c|}
\hline & & $\begin{array}{l}\text { high level. By doing so, we can } \\
\text { then be confident in maintain } \\
\text { our operating cost lean." }\end{array}$ & \\
\hline Interdependency & $\begin{array}{l}\text { The extent and frequency } \\
\text { of interactions in the } \\
\text { interconnected processes } \\
\text { and activities involved in } \\
\text { the service delivery } \\
\text { operations under the } \\
\text { scope of the improvement } \\
\text { project. }\end{array}$ & $\begin{array}{l}\text { "I think the whole focus of this } \\
\text { has not always been around the } \\
\text { patients' journey and an } \\
\text { integrated flow concept. This } \\
\text { project has brought about a fresh } \\
\text { perspective to the focus of our } \\
\text { improvement efforts that are } \\
\text { motivated towards providing } \\
\text { better and safer care for our } \\
\text { patients." }\end{array}$ & $\begin{array}{l}\text { RIE 7: } \\
\text { Focused care } \\
\text { for elderly } \\
\text { patients }\end{array}$ \\
\hline $\begin{array}{l}\text { Uniqueness of } \\
\text { Services }\end{array}$ & $\begin{array}{l}\text { The degree of } \\
\text { repeatability of the } \\
\text { services combined with } \\
\text { the degree of discretion, } \\
\text { freedom, and decision- } \\
\text { making power in } \\
\text { selecting services offered } \\
\text { to the patients. The higher } \\
\text { the repeatability of the } \\
\text { service the less unique the } \\
\text { service offered. }\end{array}$ & $\begin{array}{l}\text { "In our profession, the nature of } \\
\text { work is highly specialized. It is } \\
\text { very difficult to be easily } \\
\text { replaceable by machines or } \\
\text { automation in the near term, } \\
\text { especially if you are talking } \\
\text { about patient care. It is } \\
\text { important to have the intrinsic } \\
\text { touch and personalized care and } \\
\text { attention. It is hard to provide } \\
\text { that kind of patient care and } \\
\text { treatment needed without an } \\
\text { available pool of rightly skilled } \\
\text { manpower and expertise." }\end{array}$ & $\begin{array}{l}\text { RIE 2: } \\
\text { Surgical } \\
\text { department }\end{array}$ \\
\hline
\end{tabular}

\section{FINDINGS}

\subsection{Within Case Analysis of Single Department Projects}

\subsubsection{RIE 1: Inpatient ward discharge process}

Due to bed shortages in Hospital A, the inpatient ward was under pressure to expedite its in-patient discharge process. The objective of this RIE was to improve the discharge rate of the inpatient ward by streamlining the internal discharge processes. The primary focus was on reducing waste within the ward operations. There was little to almost no regard for the external parties who might have been connected to the ward processes. The project began by drawing on the central philosophy of lean and focusing on eliminating muda (waste) or processes that do not add value to patients. The team carried out mapping of their internal 
processes and aimed to cut down waste identified within their specific work area. The overriding focus in the RIE was on eliminating any forms of excess that were perceived as wasteful to the operations. The project leaders took great care to confine the scope of the RIE to problems of waste and inefficiency within its span of control.

\subsubsection{RIE 2: Surgical department operations}

The objectives of RIE 2 were to optimize the use of surgical resources in the department and improve internal operational performance of the surgical department in Hospital A. The RIE involved only the internal personnel in the surgical department. Brainstorming for solutions was focused solely on alleviating the current situations of no-shows and missed appointments through the identification of eight wastes based on a template of 'DOWNTIME', an acronym for eight forms of waste - Defects, Over-production, Waiting, not using staff talent, Transportation, Inventory, Motion, and Excessive-processing. A usual project agenda like the format carried out at the inpatient ward discharge process (RIE 1) was adopted. There was little or almost no evidence of cognition of a flow concept and integration of organizational interfaces. This approach resulted in a focus on internal resource efficiency within the department and an emphasis on elimination of resource redundancy commonly perceived as wastes.

\subsubsection{RIE 3: Echocardiography (ECHO) department}

ECHO department was a specialized service area that provided patient imaging services using the Cardiac Echocardiography Machine. Like the surgical department, the ECHO department's core motivation was to make optimal use of the expensive capital resource. The practice of personnel within the department had always been geared toward optimizing the use of the available machine; idle time was not condoned. This was due to the high capital cost and huge investment in medical technology and equipment in the department. Therefore, 
there was an intuitive motivation to make sure none of these capital investments were wasted.

\subsection{Within Case Analysis of Inter-Department Improvement Projects}

\subsubsection{RIE 4: Cancer center}

The cancer center provided core treatment services, such as chemotherapy, that were multi-step processes involving multidisciplinary groups. The goal of this project was to improve the overall efficiency of the chemotherapy process in an oncology infusion center by implementing changes that would decrease patient waiting times and improve communication across disciplines. Therefore, the dominant focus was on timely communication, coordination, and the sharing of patient information to create flow and quick response to patient demand, so a safer, streamlined visit could be achieved to enhance patients' experiences.

As resources/functions were reserved for the fulfillment of patient needs, there were times when they were idle. With the patient being the focus, the resources/functions were pulled to meet the patients' needs. Staff worked as a team with a common goal of meeting patient needs.

\subsubsection{RIE 5: Housekeeping operations}

The housekeeping operation was a supporting function that cut across several functions and processes in the hospital. Due to this inherent nature of the housekeeping operations, it acted primarily in response to job requests of the central operations units of the hospital. To satisfy the increasing demand for housekeeping operations, the housekeeping department had initiated a RIE that focused on improving current operations practices and management of existing processes. The RIE involved personnel within the housekeeping department, as well as personnel from interfacing departments. In addition, members of the RIE had agreed on several cross-departmental outcome measures for subsequent monitoring of the changes and new work practices that were carried out. The fundamental aims were to improve information 
exchange and coordination to reduce waiting time for inpatient transfers and admission.

\subsubsection{RIE 6: Closed loop dispensary system}

To improve drug replenishment accuracy and reduce the replenishment lead-time, a new automated closed loop replenishment system was implemented. The undesirable implications of drug complications and ingrained notion of ensuring patient safety helped to prioritize process integration across the various interfaces at the pharmaceutical store, wards, outpatient services, and drug dispensary counters. The aim of this project was to bridge the gaps within separate functional groups. While the intended objective of the inter-departmental RIE was not on waste elimination, there was reduced time to undertake specific duties, thereby reducing waste and releasing capacity when greater coordination was achieved through the integration of departmental interfaces.

\subsubsection{RIE 7: Focused care for elderly patients}

In this project, resources such as beds and supporting assets were ring-fenced for elderly patients who required acute care. This group involved inter-disciplinary collaboration for the delivery of specific healthcare recovery and living support to the elderly patients. There was an acceptance that the ring-fenced (dedicated) resources would be lying idle if the patients did not use them. However, the project team believed this was necessary to ensure the presence of protective capacity and buffer to provide the required care, in a timely manner, to the growing elderly population. The goal for the improvement project was ensuring the efficient flow of elderly patients who required specialized care.

\subsubsection{RIE 8: Death registration process}

Death registration was a complex process that had to be completed within twenty-four hours. It typically involved several departments at the public hospital. As the process typically involved more labor resources relative to capital resources, the focus was to ensure 
timely coordination among the various departments to facilitate an integrated workflow. The informants from this inter-department project repeatedly mentioned that their work activities were intricately complex, connected, and inter-dependent. This conception was illustrated by the way the system boundaries were defined. In this project, the system boundaries were clearly defined across departments in the hospitals and extended throughout the entire treatment delivery pathway of the patient.

\subsection{Cross-Case Analysis - Comparative Analysis of Single Department Projects versus Inter-Department Projects}

\subsubsection{Focus on the type of efficiency-Evidence of efficiency paradox}

\section{Project with a Resource Efficiency Focus}

In the single department projects, the primary focus was to optimize the use of existing resources within the department. There was a gap in understanding that resources and elements required in the process of administering patient care are interconnected across departments and these required bridging and integration to facilitate the patients' care in the hospital. There was very little understanding of how the improvements brought about by the single department's lean efforts would impact their colleagues in other departments.

For instance, RIE 1 was focused on maximizing the turnaround frequency of beds in the inpatient ward. Therefore, the aim of the lean project was to shorten patients' length of stay, so the performance measurement was based on tracking the number of patient discharges before noon (per day). The staff that were involved in facilitating and administrating patients' discharge process, including both clinicians and administrative staff, were aligned to meet this directive. In the process, thorough assessments of whether the patient had recovered sufficiently to cope with his/her daily needs after discharge were neglected.

Other than RIE 1, RIE 2 and 3 were also focused on resource efficiency. The core 
motivation of both RIE 2 and RIE 3 was to maximize the usage of available capacities, resources, and job functions involved in the processes within the Surgical and Cardiac Echocardiography departments. Idle time was not condoned. The focus was to optimize the utilization of the resources involved in lean projects to maximize the use of the individual resources at the departmental or sub-unit level. With most of the time spent on optimizing the internal functions and resources within a single department, this resulted in little communication across departments. Individual departments functioned as silos, with little regard to how other departments were functioning within the same organization. The outcomes were long throughput time, many flow units, and numerous restarts resulting from many handovers across departments. This resulted in long wait times for patients and delays in patients' subsequent stages of diagnosis.

\section{Projects with a Flow Efficiency Focus}

In stark contrast, RIE 7 was substantially different from the RIE 1, 2 and 3. It was initiated with an aim to arrest the problem of repeated returns of "frequent flyers", a label the hospital had used to describe returning elderly patients who were readmitted to the hospital within a month of being discharged. The focus of RIE 7 was on creating a one-stop care for elderly patients, who were likely to require multi-disciplinary care and support that cut across functions and departments within the hospital. Therefore, the project scope and team composition of RIE 7 involved multiple departments and job functions in the hospital. The performance indicator that was tracked in RIE 7 was fundamentally based on the flow of the individual unit of interest; the patient who was served.

In RIE 7, capacities and resources were reserved to ensure that the required specialists and functions were available to cater to the needs of elderly patients readily in the focused care program. As resources from the required specialties were pulled to serve the needs of the 
patient in a timely manner, there were times when the resources were not used or were idle.

Similar focus was observed in RIE 4 and RIE 5, where the motivation was very much centered on fulfilling patients' needs. Inter-departmental interactions and coordination among multiple job functions were the salient issues in these projects. Another interesting observation from our case analysis was that, if there was concern with regard to patient safety within a RIE, the dominant focus was on fulfilling the needs of the patient by ensuring a smooth flow of the services required to meet their needs.

In sum, unlike the single department projects where the focus was mainly on tracking utilization rates of specific resources within the department, inter-departmental projects (RIEs 4 to 8 ) were distinct in that their primary focus was on enhancing patient flow. Due to this vision, the different departments could work toward a common goal. These inter-department projects took a predominantly flow-based view. The multiple departments recognized their inherent interdependency and acknowledged that patients' experience was not the work of a single department, but required collaborative work from various interconnected departments along the patient's journey. Their predominant focus was on flow efficiency. The expected outcomes of these projects had been largely successful.

\subsubsection{Views on waste}

In contrast to the single department, lean projects that had a primary interest in the elimination of waste, there was little or no emphasis on the elimination of resource redundancy in work areas in the inter-department projects. Generally, there was a recognition that having some forms of resource redundancy acted as a buffer and protective capacity in facilitating the flow of patients across the hospital system. The focus was on how to achieve the required support from the interconnected resources and sub-units that were part of the service delivery chain. This was evidence of a patient-centered view in the inter-departmental projects, which was a strong motivating force that brought the distinct groups, separated by 
the departmental boundaries, to work collaboratively throughout the inter-departmental improvement projects.

Table 5 provides a summary of the forms of established attributes that are observed at the respective lean projects based on the first phase data coding and analysis. 
Table 5: Attributes of lean projects (RIEs) cases

\begin{tabular}{|c|c|c|c|c|c|c|c|c|}
\hline \multirow{2}{*}{$\begin{array}{l}\text { Lean project } \\
\text { (RIE) }\end{array}$} & \multirow{2}{*}{$\begin{array}{l}\text { Focus } \\
\text { (Resources/ Functions } \\
\text { or Unit) }\end{array}$} & \multirow{2}{*}{$\begin{array}{l}\text { Goal } \\
\text { (High capacity } \\
\text { utilization/ } \\
\text { Fulfill needs) }\end{array}$} & \multirow{2}{*}{$\begin{array}{l}\text { Views on } \\
\text { organization } \\
\text { (Organization as } \\
\text { parts/ "islands" } \\
\text { Or } \\
\text { Organization as } \\
\text { System/ } \\
\text { "Ocean") }\end{array}$} & \multirow{2}{*}{$\begin{array}{l}\text { Competence } \\
\text { (Specialist/ } \\
\text { "Depth" } \\
\text { Or } \\
\text { Multi- } \\
\text { Competence/ } \\
\text { "Width") }\end{array}$} & \multirow{2}{*}{$\begin{array}{l}\text { Dominant } \\
\text { Types of } \\
\text { Needs } \\
\text { Fulfilled } \\
\text { (Direct/ } \\
\text { Indirect) }\end{array}$} & \multicolumn{3}{|c|}{ Outcomes } \\
\hline & & & & & & $\begin{array}{l}\text { Throughput } \\
\text { time } \\
\text { (Long/Short) }\end{array}$ & $\begin{array}{l}\text { Number of } \\
\text { Units } \\
\text { (Many/Few) }\end{array}$ & $\begin{array}{l}\text { Restarts } \\
\text { (Many/ } \\
\text { Few) }\end{array}$ \\
\hline $\begin{array}{l}\text { (1) Inpatient ward } \\
\text { discharge process }\end{array}$ & $\begin{array}{l}\text { Resources (e.g., beds, } \\
\text { clinicians)/Functions } \\
\text { (housekeeping services } \\
\text { in bed turnaround) }\end{array}$ & $\begin{array}{l}\text { High Capacity } \\
\text { Utilization }\end{array}$ & $\begin{array}{l}\text { Organization as } \\
\text { parts/"islands" }\end{array}$ & $\begin{array}{l}\text { Specialist/ } \\
\text { "Depth" }\end{array}$ & Direct & $\begin{array}{l}\text { Long } \\
\text { (Occupancy } \\
\text { rate of } \\
\text { hospitals } \\
\text { were over } \\
100 \% \text { and } \\
\text { waiting time } \\
\text { for a bed was } \\
\text { on average } 1 \\
\text { to } 1.5 \text { days.) } \\
\end{array}$ & $\begin{array}{l}\text { Many } \\
\text { (Flow units in } \\
\text { the process to } \\
\text { ensure } \\
\text { optimization of } \\
\text { the focal } \\
\text { resource and } \\
\text { function.) }\end{array}$ & Many \\
\hline $\begin{array}{l}\text { (2) Surgical } \\
\text { Department } \\
\text { operations }\end{array}$ & $\begin{array}{l}\text { Resources/Functions } \\
\text { (Expensive surgical } \\
\text { equipment, facilities } \\
\text { and surgeons) }\end{array}$ & $\begin{array}{l}\text { High Capacity } \\
\text { Utilization }\end{array}$ & $\begin{array}{l}\text { Organization as } \\
\text { parts/"islands" }\end{array}$ & $\begin{array}{l}\text { Specialist/ } \\
\text { "Depth" }\end{array}$ & Direct & Long & Many & Many \\
\hline $\begin{array}{l}\text { (3) ECHO } \\
\text { (Cardiac } \\
\text { Echocardiography } \\
\text { Machine) }\end{array}$ & $\begin{array}{l}\text { Resources/Functions } \\
\text { (Cardiac examination } \\
\text { medical devices and } \\
\text { equipment) }\end{array}$ & $\begin{array}{l}\text { High Capacity } \\
\text { Utilization }\end{array}$ & $\begin{array}{l}\text { Organization as } \\
\text { parts/“islands" }\end{array}$ & $\begin{array}{l}\text { Specialist/ } \\
\text { "Depth" }\end{array}$ & Direct & Long & Many & Many \\
\hline $\begin{array}{l}\text { (4) Oncology } \\
\text { department/ } \\
\text { Cancer center }\end{array}$ & $\begin{array}{l}\text { Unit } \\
\text { Cancer patients who are } \\
\text { undergoing intensive } \\
\text { cancer treatment } \\
\text { involving concurrent } \\
\text { clinical administration } \\
\text { of the chemotherapy } \\
\text { and radiography }\end{array}$ & $\begin{array}{l}\text { Fulfill Patient's } \\
\text { Needs }\end{array}$ & $\begin{array}{l}\text { Organization as } \\
\text { System/“'Ocean" }\end{array}$ & $\begin{array}{l}\text { Multi- } \\
\text { Competence/ } \\
\text { "Width" }\end{array}$ & $\begin{array}{l}\text { Direct and } \\
\text { Indirect } \\
\text { Administer } \\
\text { treatment and } \\
\text { exercise high } \\
\text { level of care }\end{array}$ & Short & Few & Few \\
\hline
\end{tabular}




\begin{tabular}{|c|c|c|c|c|c|c|c|c|}
\hline $\begin{array}{l}\text { (5) Housekeeping } \\
\text { operations }\end{array}$ & $\begin{array}{l}\text { Unit } \\
\text { Focus on the flow as } \\
\text { the service is critical in } \\
\text { ensuring the timely bed } \\
\text { turnover in wards for } \\
\text { speedy admission }\end{array}$ & $\begin{array}{l}\text { Fulfill Patient's } \\
\text { Needs }\end{array}$ & $\begin{array}{l}\text { Organization as } \\
\text { System/“'Ocean" }\end{array}$ & $\begin{array}{l}\text { Multi- } \\
\text { Competence/ } \\
\text { "Width" }\end{array}$ & $\begin{array}{l}\text { Direct } \\
\text { Perform } \\
\text { required } \\
\text { housekeeping } \\
\text { operations }\end{array}$ & Short & $\begin{array}{l}\text { Few } \\
\text { (Buffer and } \\
\text { spare capacity } \\
\text { were built in. } \\
\text { In addition, } \\
\text { automation } \\
\text { was explored } \\
\text { and piloted } \\
\text { recently.) }\end{array}$ & Few \\
\hline $\begin{array}{l}\text { (6) Closed Loop } \\
\text { dispensary system }\end{array}$ & $\begin{array}{l}\text { Unit } \\
\text { Focus on flow as } \\
\text { dispensary for } \\
\text { outpatient and inpatient } \\
\text { administration is often } \\
\text { the final touchpoint in } \\
\text { the hospital where } \\
\text { patients make the } \\
\text { necessary payments and } \\
\text { leave the hospital }\end{array}$ & $\begin{array}{l}\text { Fulfill Patient's } \\
\text { Needs }\end{array}$ & $\begin{array}{l}\text { Organization as } \\
\text { System/ "Ocean" }\end{array}$ & $\begin{array}{l}\text { Multi- } \\
\text { Competence/ } \\
\text { "Width" }\end{array}$ & $\begin{array}{l}\begin{array}{l}\text { Direct } \\
\text { (dispensary) }\end{array}\end{array}$ & $\begin{array}{l}\text { Short } \\
\text { (Compared to } \\
\text { the manual } \\
\text { dispensary } \\
\text { system, the } \\
\text { automated } \\
\text { closed loop } \\
\text { dispensary } \\
\text { greatly } \\
\text { reduced } \\
\text { human effort } \\
\text { and errors in } \\
\text { drugs } \\
\text { dispensary.) }\end{array}$ & $\begin{array}{l}\text { Few } \\
\text { (The } \\
\text { dispensary } \\
\text { system was } \\
\text { running } \\
\text { 365days/24hrs) }\end{array}$ & Few \\
\hline $\begin{array}{l}\text { (7) Focused care } \\
\text { program for } \\
\text { elderly patients }\end{array}$ & $\begin{array}{l}\text { Unit } \\
\text { Focus of the program } \\
\text { was on ensuring } \\
\text { multiple needs of } \\
\text { elderly patients are } \\
\text { fulfilled via a one-stop } \\
\text { interdisciplinary unit } \\
\text { where multiple } \\
\text { departments work as a } \\
\text { team to meet the needs } \\
\text { of the patient }\end{array}$ & $\begin{array}{l}\text { Fulfill Patient's } \\
\text { Needs }\end{array}$ & $\begin{array}{l}\text { Organization as } \\
\text { System/ "Ocean" }\end{array}$ & $\begin{array}{l}\text { Multi- } \\
\text { Competence/ } \\
\text { "Width" }\end{array}$ & $\begin{array}{l}\text { Direct and } \\
\text { Indirect } \\
\text { (patient } \\
\text { centric) }\end{array}$ & $\begin{array}{l}\text { Short } \\
\text { (Compared to } \\
\text { the } \\
\text { conventional } \\
\text { approach } \\
\text { where there } \\
\text { were multiple } \\
\text { touch points } \\
\text { within the } \\
\text { hospital, the } \\
\text { wait time/ } \\
\text { throughput } \\
\text { time } \\
\text { measured in }\end{array}$ & Few & Few \\
\hline
\end{tabular}




\begin{tabular}{|c|c|c|c|c|c|c|c|c|}
\hline & & & & & & $\begin{array}{l}\text { this focused } \\
\text { care program } \\
\text { is shorter) }\end{array}$ & & \\
\hline $\begin{array}{l}\text { (8) Death } \\
\text { Registration } \\
\text { process }\end{array}$ & $\begin{array}{l}\text { Unit } \\
\text { Focus on smooth } \\
\text { administration of the } \\
\text { necessary paperwork } \\
\text { that involves multiple } \\
\text { functions and } \\
\text { departments so that the } \\
\text { required procedures for } \\
\text { death registration can } \\
\text { be completed speedily. }\end{array}$ & $\begin{array}{l}\text { Fulfill Patient's } \\
\text { Needs }\end{array}$ & $\begin{array}{l}\text { Organization as } \\
\text { System/“Ocean", }\end{array}$ & $\begin{array}{l}\text { Multi- } \\
\text { Competence/ } \\
\text { "Width" }\end{array}$ & $\begin{array}{l}\text { Direct and } \\
\text { Indirect } \\
\text { (Besides the } \\
\text { necessary } \\
\text { documentary } \\
\text { fulfillment, } \\
\text { sensitivity and } \\
\text { empathy } \\
\text { toward the next } \\
\text { of kin were } \\
\text { critical in the } \\
\text { process) }\end{array}$ & $\begin{array}{l}\text { Short } \\
\text { (Turnaround } \\
\text { was to be } \\
\text { within a day.) }\end{array}$ & Few & Few \\
\hline
\end{tabular}




\section{CONTEXTUAL ATTRIBUTES OF LEAN PROJECTS}

Table 6 provides a summary of the project descriptions, the intensity level of the contextual factors (ranging from low to high), and the resulting efficiency outcomes of the lean projects. The relative intensity of the contextual themes was evaluated using a constant comparative method, where the relevant data was repeatedly compared across the multiple projects. 
Table 6: Overview of the lean projects (RIEs), contextual attributes and efficiency outcomes

\begin{tabular}{|c|c|c|c|c|c|c|}
\hline \multirow[t]{2}{*}{ Lean project (RIE) } & \multirow[t]{2}{*}{ Project description and scope } & \multicolumn{4}{|c|}{ Contextual factor } & \multirow{2}{*}{$\begin{array}{l}\text { Efficiency } \\
\text { outcome* }\end{array}$} \\
\hline & & Service variety & Interdependency & $\begin{array}{l}\text { Uniqueness of } \\
\text { Services }\end{array}$ & $\begin{array}{l}\text { Capital } \\
\text { resource } \\
\text { intensity }\end{array}$ & \\
\hline $\begin{array}{l}\text { (1) Inpatient ward } \\
\text { discharge process }\end{array}$ & $\begin{array}{l}\text { To achieve more patients' discharge } \\
\text { before noon by increasing usage of } \\
\text { discharge lounge facilities in ward }\end{array}$ & $\begin{array}{l}\text { Low/Medium } \\
\text { (General in-patient } \\
\text { ward services) }\end{array}$ & Low/Medium & Medium/High & Medium/High & $\begin{array}{l}\text { Resource } \\
\text { efficiency }>\text { Flow } \\
\text { efficiency }\end{array}$ \\
\hline $\begin{array}{l}\text { (2) Surgical Department } \\
\text { operations }\end{array}$ & $\begin{array}{l}\text { To reduce the number of no shows } \\
\text { and cancellations with internal work } \\
\text { flow redesign - Target less than } 10 \% \\
\text { no-shows or cancellations }\end{array}$ & $\begin{array}{l}\text { Low (Generic suite } \\
\text { of surgical } \\
\text { procedures offered) }\end{array}$ & Low & High & High & $\begin{array}{l}\text { Resource } \\
\text { efficiency } \\
\text { dominant }\end{array}$ \\
\hline $\begin{array}{l}\text { (3) ECHO (Cardiac } \\
\text { Echocardiography } \\
\text { Machine) }\end{array}$ & $\begin{array}{l}\text { To maximize the use of existing } \\
\text { Cardiac Echocardiography Machine } \\
\text { and peripheral resources }\end{array}$ & $\begin{array}{l}\text { Low (Generic } \\
\text { ECHO imaging) }\end{array}$ & Low & High & High & $\begin{array}{l}\text { Resource } \\
\text { efficiency } \\
\text { dominant }\end{array}$ \\
\hline $\begin{array}{l}\text { (4) Oncology department/ } \\
\text { Cancer center }\end{array}$ & $\begin{array}{l}\text { To coordinate appointment booking } \\
\text { and treatment processes of both } \\
\text { radiography and chemotherapy }\end{array}$ & Medium/High & Medium/High & Low/Medium & Low/Medium & $\begin{array}{l}\text { Flow efficiency } \\
\text { >> Resource } \\
\text { efficiency }\end{array}$ \\
\hline $\begin{array}{l}\text { (5) Housekeeping } \\
\text { operations }\end{array}$ & $\begin{array}{l}\text { To satisfy greater demand through } \\
\text { management of existing processes }\end{array}$ & High & High & Low & Low & $\begin{array}{l}\text { Flow efficiency } \\
\text { dominant }\end{array}$ \\
\hline $\begin{array}{l}\text { (6) Closed Loop } \\
\text { dispensary system }\end{array}$ & $\begin{array}{l}\text { To achieve and coordinate better } \\
\text { accuracy of drug replenishments in } \\
\text { the wards }\end{array}$ & Medium/High & Medium/High & Low/Medium & Low/Medium & $\begin{array}{l}\text { Flow efficiency > } \\
\text { Resource } \\
\text { efficiency }\end{array}$ \\
\hline $\begin{array}{l}\text { (7) Focused care program } \\
\text { for elderly patients }\end{array}$ & $\begin{array}{l}\text { To direct better care toward elderly } \\
\text { patients who require acute care } \\
\text { support (an interdisciplinary care } \\
\text { program) }\end{array}$ & High & High & Low & Low & $\begin{array}{l}\text { Flow efficiency } \\
\text { dominant }\end{array}$ \\
\hline $\begin{array}{l}\text { (8) Death Registration } \\
\text { process }\end{array}$ & $\begin{array}{l}\text { To speed up the process and lead } \\
\text { time of death registration within the } \\
\text { hospital }\end{array}$ & Medium/ High & Medium/ High & Low/ Medium & Low/ Medium & $\begin{array}{l}\text { Flow efficiency } \\
\text { >> Resource } \\
\text { efficiency }\end{array}$ \\
\hline
\end{tabular}

$*>$ or $>>$ indicate the relative extent of resource efficiency focus or flow efficiency focus 


\subsection{Propositions}

\subsubsection{Contextual factor: Service variety}

The first contextual factor, service variety, refers to the range of distinct services offered under the scope of the improvement project. Departments that had to provide a wider range of services often dealt with external parties outside of their departments in the scope of their service deliveries. As such, they tended to focus on flow issues, and ensure that external parties were involved and engaged in the service improvement processes. Without this focus, it would have been difficult to generate performance outcomes that enhanced patient flow across the hospital system. On the other hand, departments that had a narrow range of services focused on ensuring a high degree of utilization of the capital resources in the provision of those services. Examples of projects that had high levels of service variety were housekeeping operations (RIE 5) and focused care for elderly patients (RIE 7). Projects with low service variety were the surgical department operations (RIE 3) and echocardiography department (RIE 3). We, therefore, posit that service variety exerts its influence on lean projects in the following manner:

Proposition 1: Lean projects that involve a myriad range of services are more likely to conceive system boundaries beyond a single functional group and emphasize external constraints, thus achieving flow efficiency focus.

\subsubsection{Contextual factor: Interdependency}

For the second contextual factor, interdependency, departments that were highly dependent on other external departments in their service delivery processes tended to adopt a flow-based view and perceive boundaries of the systems beyond the confinement of a single functional group/department. This was because they required collaborative support from other functional units in enabling their own work activities that often cut across several 
disciplinary groups. Thus, it was in their interest to call on collaborative interest among the other departments so their work activities could be carried out effectively. Examples of these inter-department projects that involved high need for dependent departments to collaborate were: the cancer center (RIE 4); housekeeping operations (RIE 5); the closed loop dispensary (RIE 6); focused care for elderly patients (RIE 7); and death registration (RIE 8). Hence, we propose that:

Proposition 2: Lean projects that involve more interdependent functional groups are more likely to conceive system boundaries beyond a single functional group and emphasize external constraints, thus achieving flow efficiency focus.

\subsubsection{Contextual factor: Capital resource intensity}

For the third contextual factor, capital resource intensity, departments that were comparatively higher in capital resource intensity had higher interest in maximizing resource use within the internal operations of a functional department. Therefore, they tended to adopt a resource-focused view. These departments were the surgical department (RIE 2) and the Echocardiography (ECHO) lab (RIE 3). On the other hand, departments that were lower in capital resource intensity tended to bear a lower interest in maximizing resource usage and were focused more on the flow of patients across departmental interfaces. Therefore:

Proposition 3: Lean projects that involve operations with high capital resource intensity are more likely to conceive system boundaries within a single functional group and emphasize internal constraints, thus achieving resources efficiency focus.

\subsubsection{Contextual factor: Uniqueness of service}

The last contextual factor, uniqueness of service, refers to the degree of discretion which resides in the hands of clinical staff and the degree of repeatability of the service. Highly unique services such as those offered at the clinically focused departments included surgical 
department operations (RIE 2) and echocardiography department (RIE 3) tended to be more resource focused. In contrast, less unique services like housekeeping operations (RIE 5) and focused care for elderly patients (RIE 7) were more intricately dependent and connected with other disciplines and departments. They manifested a sense of urgency to have integration across multiple disciplinary groups and required high levels of support in coordination to carry out their routine operations and work activity in a seamless manner. Therefore, we propose that:

Proposition 4: Lean projects that involve more unique types of services are more likely to conceive system boundaries within a single functional group and emphasize internal constraints, thus achieving resource efficiency focus.

\subsection{Conceptual Framework}

To illustrate the key findings from this study, a conceptual framework that connects the salient contextual factors and the dominant focus in lean practices is provided in Figure 2. 


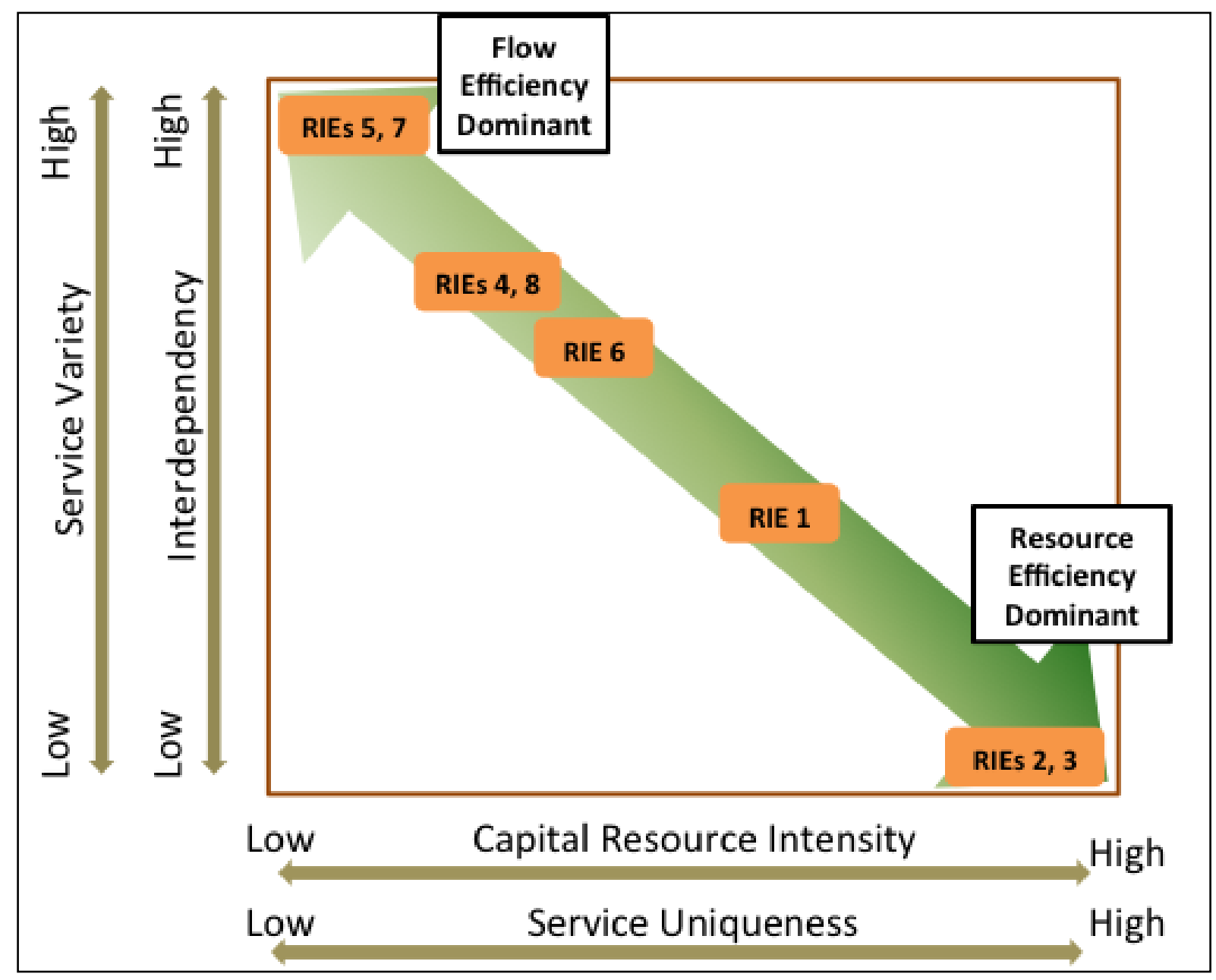

Figure 2: An integrated conceptual framework

The vertical axis shows the two contextual factors, service variety and interdependency, while the horizontal axis shows the other two, capital resource intensity and service uniqueness. The two axes and the four contextual factors are conceptually independent. In Figure 2, the diagonal continuum shows the conceptual positions of the eight lean projects described by their relative intensity of contextual factors, as determined from the constant comparative analyses. As can be seen in Figure 2, lean projects that were high in-service variety and interdependency, and low in capital resource intensity and uniqueness of services (RIEs 5 and 7), tended to adapt lean with a dominant orientation toward flow efficiency. On the other hand, lean projects that were high in capital resource intensity and uniqueness of services, and low in-service variety and interdependency (RIEs 2 and 3), tended to adapt lean 
with a dominant focus toward resource efficiency. The other lean projects (RIEs 1, 4, 6 and 8) characterized by a differential mix of contextual factors are shown in Figure 2 as occupying positions on the diagonal continuum. RIE 1 focused mainly on resource efficiency, whereas RIEs 4,6 and 8 focused primarily on flow efficiency.

\section{DISCUSSION}

In this study, we have attempted to understand how the fate of lean projects initiated within different departments in a hospital, seem pre-determined prior to implementation. We do so by conducting an in-depth study of eight RIE's conducted across two public hospitals in Singapore. At the outset, we highlight that there are two distinct types of outcomes that can be generated, depending on the focus of the lean project. The first type is focused on waste elimination (or reduction) and maximizing the efficiency of individual resources (e.g., existing staff and facilities) within a specific internal department. Our findings concur with scholars who have argued that, when the adaptation of lean is done in such a silo manner within a specific service function, it would be difficult to achieve the desired outcomes (e.g., Mazzocato et al. 2010; Young and McClean 2008). This is due to a lack of understanding of the dependency between the interconnected elements and resources within the hospital (Poksinska 2010; Radnor et al. 2012). However, when lean initiatives are focused on enhancing the flow of subjects and their experience across all the connected processes in the service delivery chain, this will lead to desired and sustained operational outcomes (e.g., Belter et al. 2012; Tucker et al. 2008).

In response to the research question: "What are the contextual factors that lead to either resource or flow efficiency focus in Lean improvement projects?", this study proposes four contextual factors and, depending on the combination in which they interact, this can determine the orientation of a project toward resource or flow efficiency. Viewing lean implementations with a different lens, we believe that an ideal incubator for the efficiency 
paradox is when high levels of capital resource intensity and service uniqueness are combined with low levels of service variety and interdependency. This lethal combination will invariably steer the project toward attaining resource efficiency and subsequently severely impact the outcomes of lean projects. Conversely, low levels of capital resource intensity and service uniqueness, combined with high levels of service variety and interdependency, will generate a dominant flow efficiency, which will sustain successful project outcomes.

Modig and Åhlström (2012) provide the building blocks for this study by providing cogent and persuasive arguments on the efficiency paradox and suggesting how operations can be optimized based on the two different forms of efficiency. In this study, we propel their arguments further by developing a deeper understanding of four contextual factors that influence the predisposition of lean projects toward flow or resource efficiency. As such, the associated propositions and conceptual framework extend our understanding of the efficiency paradox within the healthcare context.

In addition, our approach to considering individual lean improvement projects within hospitals as the primary unit of analysis allows us to decipher contextual factors that are salient across different departments in these hospitals. Our study provides a more refined understanding of a couple of issues that have surfaced in the lean literature within healthcare settings: "context matters" and "one size does not fit all” (De Souza 2009; Radnor et al. 2012; Waring and Bishop 2010). Through our study of eight RIE initiatives, we highlight the need to understand how specific contextual variables play out prior to implementing lean projects. Departments dealing with specialized services, such as the echo-cardiography department and surgical operations, are the most vulnerable to the efficiency paradox. Therefore, due diligence should be given to understanding the focus and performance measures to ensure the "voice of the patient" is the key driver. Furthermore, through the different RIEs that we have 
investigated, we not only highlight how the healthcare context is different from manufacturing, but also demonstrate that heterogeneity in lean applications is a function of how specific contextual factors can interact and play out to influence the orientation of a project toward resource or flow efficiency. In this regard, we add on to Radnor et al's (2012) findings that highlighted several impediments to lean applications in the healthcare context that has resulted from implementing lean merely as a tool based perspective and piece-wise manner.

Our study also offers various suggestions for the practitioner community. First, in a department where capital cost of a resource is high, the focus on efficiency improvement of this resource in the form of high utilization will be naturally expected. But this needs to be balanced with an equally strong focus on external aspects and flow issues by being cognizant of the impact the implemented actions may have on adjacent operations, to avoid being ensnared with the pitfalls of the efficiency paradox.

Second, the contextual factors illustrate to hospitals' leadership which departments and areas of their hospital are likely to have gaps in terms of enabling patient flow over resource flow. Contextual factors that influence the predisposition of lean projects toward flow or resource efficiency should be judiciously assessed prior to embarking on lean initiatives. For example, when personnel within a specific department are trained, they should be provided with an extensive overview of the overall hospital-level flow information and measurement and encouraged to think of the implementations from a patient's perspective.

This is specifically the case with specialist departments such as the surgical department and echo-cardiography department, where they have no information on how their interactions and resource-flow focused performance impact overall patient flow in the healthcare delivery system. Provision of this information will enable practitioners to understand the impact of their interactions in lean projects on the patient flow journey, and serve as an incentive for a 
shift toward flow focus and patient-centric care. In addition, this study calls upon healthcare managers and policy makers to reflect on the design of performance measurements and reward systems to incentivize an end-to-end process view of patient-centric care and engender a broader view of the way in which their care services are provided.

\subsection{Limitations of the Study and Future Research Possibilities}

As is generally recognized, qualitative studies suffer from lack of external validity. Our study is not an exception. The propositions developed are based on a limited amount of case data. Therefore, drawing accurate overarching generalizations from the results is not possible. To overcome this issue, the suggested conceptual framework and propositions can be translated into hypothetico-deductive statements and tested with large sets of quantitative data. The limitations of a single country case-study approach, using only public hospitals for empirical insights, also affect the generalizability of the findings. Future research can include

private hospitals and other healthcare operation contexts to investigate different sets of contextual drivers and stakeholders' influences that may be in play. Lastly, future studies can explore possible interactions of the contextual factors to provide further understanding of the influence of context on lean projects by collecting cross-departmental level data relevant to the projects.

\section{CONCLUSIONS}

The healthcare services sector that includes hospitals, aged care homes, nursing homes, and pathology clinics offers immense potential to gain from lean implementations. However, implementations have produced mixed outcomes. This is essentially because lean adaptations in healthcare are context dependent (Radnor, 2012) and, therefore, require more careful study.

Our study is a response to this call. We used lean project cases set across two major 
public hospitals in Singapore to address the research question: "What are the contextual factors that lead to either resource or flow efficiency focus in lean projects?" We identified four contextual factors that influence the focus of lean projects in service operations. As such, our study extends the lean literature and provides deepened understanding on the application of lean in service operations and project managements contexts.

This insight into contextual factors is significant, as the extant literature appears to be silent on how managers can systemically overcome the efficiency paradox and adapt lean in a more predictable way to achieve successful outcomes. The findings from this study provide an alternative way to think about outcomes of lean-based improvement initiatives, as the four contextual factors reveal the underlying conditions that create the efficiency paradox. As such, we extend our understanding of why some lean projects fail and provide ideas on how these failures can be mitigated.

\section{REFERENCES}

Ahlstrom P (2004) Lean service operations: translating lean production principles to service operations International Journal of Services Technology and Management 5:545-564

Anand G, Chhajed D, Delfin L (2012) Job autonomy, trust in leadership, and continuous improvement: An empirical study in health care Operations Management Research 5:70-80

Arkader R (2001) The Perspective of Suppliers on Lean Supply in a Developing Country Context Integrated Manufacturing Systems 12:87-93

Arlbjørn JS, Freytag PV (2013) Evidence of lean: A review of international peer-reviewed journal articles European Business Review 25:174-205

Balle M (2005) Lean Attitude Manufacturing Engineer 84:14-19

Bamford D, Forrester P, Dehe B, Leese RG (2015) Partial and iterative Lean implementation: two case studies International Journal of Operations \& Production Management $35: 702-727$

Belter D et al. (2012) Evaluation of Outpatient Oncology Services Using Lean Methodology Oncology Nursing Forum 39:136-140 
Coelli TJ, Rao DSP, O'Donnell CJ, Battese GE (2005) An introduction to efficiency and productivity analysis. $2^{\text {nd }}$ edn. Springer Science \& Business Media, New York, NY

Dahlgaard JJ, Dahlgaard-Park SM (2006) Lean production, six sigma quality, TQM and company culture The TQM Magazine 18:263 - 281

De Souza LB (2009) Trends and approaches in lean healthcare Leadership in health services 22:121-139

De Treville S, Antonakis J (2006) Could lean production job design be intrinsically motivating? Contextual, configurational, and levels-of-analysis issues Journal of Operations Management 24:99-123

DelliFraine JL, Langabeer JR, Nembhard IM (2010) Assessing the evidence of Six Sigma and Lean in the health care industry Quality Management in Healthcare 19:211-225

Eisenhardt KM (1989) Building theories from case study research Academy of Management review 14:532-550

Gioia DA, Corley KG, Hamilton AL (2013) Seeking qualitative rigor in inductive research: Notes on the Gioia methodology Organizational Research Methods 16:15-31

Hillman K, Braithwaite J, Chen J (2011) Healthcare Systems and Their (Lack of ) Integration. In: DeVita MA, Hillman K, Bellomo R (eds) Textbook of Rapid Respond Systems. Springer, New York, pp 79-86

Holweg M (2007) The genealogy of lean production Journal of Operations Management 25:420-437

Hopp WJ, Spearman ML (2004) To pull or not to pull: what is the question? Manufacturing \& Service Operations Management 6:133-148

Krafcik JF (1988) Triumph of the lean production system Sloan Management Review 30:4152

LaGanga LR (2011) Lean service operations: Reflections and new directions for capacity expansion in outpatient clinics Journal of Operations Management 29:422-433

Lee RH, Bott MJ, Gajewski B, Taunton RL (2009) Modeling Efficiency at the Process Level: An Examination of the Care Planning Process in Nursing Homes Health services research 44:15-32

Marley K, Ward P (2013) Lean management as a countermeasure for "Normal" disruptions Operations Management Research 6:44-52

Mazzocato P, Savage C, Brommels M, Aronsson H, Thor J (2010) Lean thinking in healthcare: a realist review of the literature Quality and Safety in Health Care 19:376382

McDermott C, Venditti F (2015) Implementing lean in knowledge work: Implications from a study of the hospital discharge planning process Operations Management Research:113 
Meijboom BR, Bakx SJWGC, Westert GP (2010) Continuity in health care: lessons from supply chain management The International Journal of Health Planning and Management 25:304-317

Meredith J, Grove A, Walley P, Young F, Macintyre M (2011) Are we operating effectively? A lean analysis of operating theatre changeovers Operations Management Research 4:89-98

Meyer Jr V, Pascucci L, Murphy JP (2012) Implementing Strategies in Complex Systems: Lessons from Brazilian Hospitals Brazilian Administration Review 9:19-37

Modig N, Åhlström P (2012) This is lean: Resolving the efficiency paradox. Rheologica,

New SJ (2007) Celebrating the enigma: the continuing puzzle of the Toyota Production System International Journal of Production Research 45:3545-3554

Papadopoulos T, Radnor Z, Merali Y (2011) The role of actor associations in understanding the implementation of Lean thinking in healthcare International Journal of Operations \& Production Management 31:167-191

Pegels CC (1984) The Toyota production system-lessons for American management International Journal of Operations \& Production Management 4:3-11

Poksinska B (2010) The current state of Lean implementation in health care: literature review Quality Management in Healthcare 19:319-329

Radnor Z (2010) Transferring lean into government Journal of Manufacturing Technology Management 21:411-428

Radnor Z (2011) Implementing Lean in Health Care: Making the link between the approach, readiness and sustainability International Journal of Industrial Engineering and Management 2:1-12

Radnor ZJ, Holweg M, Waring J (2012) Lean in healthcare: The unfilled promise? Social Science \& Medicine 74:364-371

Seddon J (2011) Lean is a waning fad Management Services 55:34-36

Shah R, Goldstein SM, Unger BT, Henry TD (2008) Explaining Anomalous High Performance in a Health Care Supply Chain* Decision Sciences 39:759-789

Shah R, Ward PT (2003) Lean manufacturing: context, practice bundles, and performance Journal of Operations Management 21:129-149

Shah R, Ward PT (2007) Defining and developing measures of lean production Journal of Operations Management and Organization Review 25:785-805

Spear SJ (2005) Fixing health care from the inside, today Harvard business review 83:78

Staats B, Brunner DJ, Upton DM (2011) Lean Principles, Learning, and Knowledge Work: Evidence from a Software Services Provider Journal of Operations Management 29:376-390 
Staats B, Upton DM (2011) Lean Knowledge Work Harvard Business Review 89:100-110

Stake RE (1995) The art of case study research. Sage, London

Strauss A, Corbin J (1990) Basics of Qualitative Research. Sage, Newbury Park, CA

Taylor A, Taylor M, McSweeney A (2013) Towards greater understanding of success and survival of lean systems International Journal of Production Research 51:6607-6630

Tucker AL, Singer SJ, Hayes JE, Falwell A (2008) Front-Line Staff Perspectives on Opportunities for Improving the Safety and Efficiency of Hospital Work Systems Health services research 43:1807-1829

Van Aken EM (2010) A framework for designing, managing, and improving Kaizen event programs International Journal of Productivity and Performance Management 59:641667

Van Maanen J (1979) The fact of fiction in organizational ethnography. Administration Science Quarterly 24:539-550

Waring JJ, Bishop S (2010) Lean Healthcare: Rhetoric, ritual and resistance Social Science \& Medicine 71:1332-1340

Weber D (2006) Toyota-style management drives Virginia Mason Physician executive 32:12

Womack JP, Jones DT (1996) Lean thinking: banish waste and create wealth in your corporation. Simon and Schuster, New York

Womack JP, Jones DT, Roos D (1990) The Machine that Changed the World. Rawson Associates., New York

Yin RK (2003) Case Study Research: Design and Methods. Sage, London

Young TP, McClean SI (2008) A critical look at Lean Thinking in healthcare Quality and safety in health care 17:382-386 


\section{APPENDIX A}

\section{Questions in the Semi-Structured Interview Protocol}

- How would you describe the constraints that are limiting the work processes in this project?

- What are the main causes of these limiting factors?

- How has lean affected the current practice in managing the internal operations in your service areas?

- How would you describe the impact of the lean project in your service areas?

- Is there improvement in efficiency performance?

- What outcomes have resulted from the lean practices?

- Have the expected outcome/s been achieved?

- Have the improved outcomes been able to sustain over time? 


\section{Appendix B}

\section{Representative quotes that are evidence of the contextual factors}

\begin{tabular}{|c|c|c|}
\hline $\begin{array}{l}\text { Contextua } \\
\text { I factor }\end{array}$ & Representative quote & Case \\
\hline \multirow[t]{3}{*}{$\begin{array}{l}\text { Service } \\
\text { variety }\end{array}$} & $\begin{array}{l}\text { "Let's first start by mapping the internal work flow within our department. } \\
\text { We'll map processes involving the full range of activities and services that } \\
\text { we provide from the point where patients are admitted to our ward to the } \\
\text { point where they exit our ward. In view of the wide range of processes and } \\
\text { activities, the mapping process will typically take one to two days." }\end{array}$ & $\begin{array}{l}\text { RIE 7: } \\
\text { Focused } \\
\text { care } \\
\text { program } \\
\text { for elderly } \\
\text { patients }\end{array}$ \\
\hline & $\begin{array}{l}\text { "To satisfy the increasing demand of housekeeping, there are different KPI } \\
\text { and performance measures for the various service requests. So, daily, we } \\
\text { need to carry out a wide range of work activities and tasks in order to } \\
\text { deliver the required services and care demanded by the broad spectrum of } \\
\text { patient profiles." }\end{array}$ & $\begin{array}{l}\text { RIE 5: } \\
\text { Housekeep } \\
\text { ing } \\
\text { operations }\end{array}$ \\
\hline & $\begin{array}{l}\text { "The fact is we are very much integrated. I mean, we are part of the } \\
\text { patient's flow, patient's journey. Nature of healthcare operations is } \\
\text { dynamic. Patient's needs translate to operational demands that are } \\
\text { constantly in flux. So, our key challenge is to be able to keep up with the } \\
\text { dynamism so as to meet the diverse needs of patients by performing } \\
\text { numerous tasks and services." }\end{array}$ & $\begin{array}{l}\text { RIE 8: } \\
\text { Death } \\
\text { Registratio } \\
\text { n RIE }\end{array}$ \\
\hline \multirow[t]{3}{*}{$\begin{array}{l}\text { Capital } \\
\text { cost } \\
\text { intensity }\end{array}$} & $\begin{array}{l}\text { "The objective was to optimize the use of surgical equipment. The focus in } \\
\text { this project was to boost the resource utilization rate of the high cost } \\
\text { surgical instrument and operating theatres. This was primarily through the } \\
\text { identification of eight wastes based on a template of "DOWNTIME", an } \\
\text { acronym for eight forms of wastes - Defects, Over-production, Waiting, } \\
\text { Not using staff talent, Transportation, Inventory, Motion and Excessive- } \\
\text { processing." }\end{array}$ & $\begin{array}{l}\text { RIE 2: } \\
\text { Surgical } \\
\text { departmen } \\
\text { t } \\
\text { operations }\end{array}$ \\
\hline & $\begin{array}{l}\text { "We cannot afford to have any resource lying idle. Equipment are brought } \\
\text { in at a very high cost, we need to ensure they are fully utilized at all times. } \\
\text { Idle time is definitely a waste; we have to improve the current rate of } \\
\text { utilization." }\end{array}$ & $\begin{array}{l}\text { RIE 3: } \\
\text { Echo- } \\
\text { cardiograp } \\
\text { hy } \\
\text { (ECHO) } \\
\text { departmen } \\
\mathrm{t}\end{array}$ \\
\hline & $\begin{array}{l}\text { "The understanding of process has changed since our staff attended the } \\
\text { Lean event. Our objective was to eliminate all forms of waste and expedite } \\
\text { the necessary work to be carried so as to keep our expensive medical } \\
\text { equipment utilized and operating space occupied at a high level. By doing } \\
\text { so, we can then be confident in maintaining our operating cost lean." }\end{array}$ & $\begin{array}{l}\text { RIE 2: } \\
\text { Surgical } \\
\text { departmen } \\
\text { t }\end{array}$ \\
\hline \multirow[t]{2}{*}{$\begin{array}{l}\text { Interdepen } \\
\text { dency }\end{array}$} & $\begin{array}{l}\text { "We don't want to see patients being dropped from the chain of care. It is } \\
\text { already hard for the cancer patients who are going through the concurrent } \\
\text { treatments involving an intensive period of chemotherapy. We want } \\
\text { patients to attain the optimal benefits of the chemotherapy procedure." }\end{array}$ & $\begin{array}{l}\text { RIE 4: } \\
\text { Cancer } \\
\text { center }\end{array}$ \\
\hline & $\begin{array}{l}\text { "I think the whole focus of this has not always been around the patients' } \\
\text { journey and an integrated flow concept. This project has brought about a } \\
\text { fresh perspective to the focus of our improvement efforts that are motivated }\end{array}$ & $\begin{array}{l}\text { RIE 7: } \\
\text { Focused } \\
\text { care for }\end{array}$ \\
\hline
\end{tabular}




\begin{tabular}{|l|l|l|}
\hline \multirow{1}{*}{} & towards providing better and safer care for our patients" & $\begin{array}{l}\text { elderly } \\
\text { patients }\end{array}$ \\
\cline { 2 - 3 } & $\begin{array}{l}\text { "These projects made use of the patient journey map as the basis of their } \\
\text { value stream mapping. The term that was prolifically used in this exercise } \\
\text { was: "We map the value streams from the patients' perspective. As a result } \\
\text { of this clear vision, the different departments were able to work } \\
\text { harmoniously towards a common goal." }\end{array}$ & $\begin{array}{l}\text { RIE 8: } \\
\text { Death } \\
\text { registratio } \\
\text { n process }\end{array}$ \\
\hline $\begin{array}{l}\text { Uniquenes } \\
\text { Services }\end{array}$ & $\begin{array}{l}\text { "I think we need to be cautious about silo thinking and spot reduction of } \\
\text { "fats" in the organization (hospital). If we are primarily focused on quick } \\
\text { wins and short term performance outcomes at a localized level, I am afraid } \\
\text { we will only end up with more hidden problems down the road." }\end{array}$ & $\begin{array}{l}\text { RIE 6: } \\
\text { Closed } \\
\text { loop } \\
\text { dispensary } \\
\text { system }\end{array}$ \\
\cline { 2 - 3 } & $\begin{array}{l}\text { "Last time, we used to make-do within our means. But now, we spend time } \\
\text { discussing problems and work issues involving different departments a lot } \\
\text { more. There are people who think that the ring-fenced resources are waste } \\
\text { or redundancy if they are not occupied and used. But our work requires a } \\
\text { high level of attention and special care to be catered to the elderly and frail; } \\
\text { they (the elderly patients) require a high level of care and attention 24/7. } \\
\text { We would not have the extra resource to work with other department } \\
\text { without the ring-fenced resources (dedicated resource and staff time). So, it } \\
\text { actually supported our work." }\end{array}$ & $\begin{array}{l}\text { Focused } \\
\text { care for } \\
\text { elderly } \\
\text { patients }\end{array}$ \\
\cline { 2 - 3 } & $\begin{array}{l}\text { "In our profession, the nature of work is highly specialized. It is very } \\
\text { difficult to be easily replaceable by machines or automation in the near } \\
\text { term, especially if you are talking about patient care. It is important to have } \\
\text { the intrinsic touch and personalized care and attention. It is hard to provide } \\
\text { that kind of patient care and treatment needed without an available pool of } \\
\text { rightly skilled manpower and expertise." }\end{array}$ & $\begin{array}{l}\text { RIE 4: } \\
\text { Cancer } \\
\text { center }\end{array}$ \\
\hline
\end{tabular}




\section{University Library}

\section{- M M N E R VA A gateway to Melbourne's research publications}

Minerva Access is the Institutional Repository of The University of Melbourne

Author/s:

Tay, HL;Singh, PJ;Bhakoo, V;Al-Balushi, S

Title:

Contextual factors: assessing their influence on flow or resource efficiency orientations in healthcare lean projects

Date:

2017-12-01

\section{Citation:}

Tay, H. L., Singh, P. J., Bhakoo, V. \& Al-Balushi, S. (2017). Contextual factors: assessing their influence on flow or resource efficiency orientations in healthcare lean projects. Operations Management Research, 10 (3-4), pp.118-136. https://doi.org/10.1007/s12063-017-0126-3.

Persistent Link:

http://hdl.handle.net/11343/283190 